\title{
Differences between Sand and Gravel Bars of Streams in Patterns of Vegetation Succession
}

\author{
Lee, Chang-Seok ${ }^{1}$, Yong-Chan Cho², Hyun-Cheol Shin ${ }^{2}$ and Sung-Ae Park ${ }^{2 *}$ \\ ${ }^{1}$ Faculty of Environment and Life Sciences, Seoul Women's University, Seoul 139-774, Korea \\ ${ }^{2}$ Department of Biology, Graduate School of Seoul Women's University, Seoul 139-774, Korea
}

\begin{abstract}
We analyzed the factors driving succession and the structure, and dynamics of vegetation on sand and gravel bars in order to clarify the differences in vegetation succession in rivers with different river bed substrates. Woody plant communities (dominated by Salix), perennial herb communities (dominated by Miscanthus), and annual plant communities (dominated by Persicaria) appeared in that order from upstream to downstream on the sandbar. The results of DCA ordination based on vegetation data reflected a successional trend. This result suggests that sandbars grow in a downstream direction. Various vegetation types different in successional stage, such as grassland, young stands of Korean red pine (Pinus densiflora), two-layered stands of young and mature pines, and mature pine stands also occurred on gravel bars, but the vegetation in earlier successional stage was established upstream, which is the opposite to the direction found on sandbars. Those results demonstrate that the dynamics of the bed load itself could be a factor affecting vegetation succession in rivers. In fact, sands suspended by running water were transported downstream over the vegetated area of sand bar and thereby created new areas of sandbar on the downstream end of the sandbar. Meanwhile, gravel, which is heavy and thereby is shifted by strong water currents, accumulated on the upstream end of the vegetated area, and thus created new areas of gravel bar in that direction. These results showed that allogenic processes drive vegetation succession on sand and gravel bars in streams and rivers.
\end{abstract}

Key words: Allogenic process, Gravel bar, Sand bar, Succession, Vegetation

\section{INTRODUCTION}

Plant ecologists usually recognize two main patterns of vegetation dynamics: succession on the one hand, and mosaic and cyclic processes on the other (Miles 1979, van Andel et al. 1993, McCook 1994). Succession is a gradual process of ecosystem development that proceeds toward relatively stable conditions following some kinds of disturbances. Mosaic or cyclical processes are smaller scale dynamics or mini-successions by which the character of stable vegetation is maintained (Watt 1947, White and Pickett 1985, van der Maarel and Sykes 1993). In research on both kinds of dynamic processes, plant ecologists have focused predominantly on the internal mechanistic (autogenic processes) that bring about ecosystem development.

External or allogenic processes (for example the creation of an area of fresh surface following landslide) are also recognized as important for initiating succession or for inducing successional change from one state to another. However, ever since Clements (1916) first introduced the concept of succession, ecologists have bee mainly interested in the ways in which plants themselves modify their environment and thus determine the successional sequence (Barbour et al. 1999). With the interest of plant ecologist in autogenic processes dominating the discussion, there is danger that we may fail to appreciate how external processes can intervene in ecosystem development.

Décamps (1996) and Chun et al. (2007) have pointed out that one can observe a sharp contrast between the forest dynamics in the active floodplains of rivers, i.e., the part of the floodplain that is regularly flooded during moderate flow events, and those on former floodplains, i.e., river terraces. Sequential succession and mosaic forests within the active floodplain are regenerated through allogenic processes such as hydrological events, whereas forests on river terraces are regenerated through autogenic processes such as competition and gap formation. Many studies have described successional processes on river terraces of different ages. However, these terraces have become isolated from the river channel, and their sequence of vegetation changes has thus been largely determined by autogenic processes (e.g., Bliss and Cantlon 1957, Wistendahl 1958, Weaver 1960, Fonda 1974, Walker and Chapin 1986). Conversely, he sand and gravel bars chosen for this study resemble sites in the active floodplain as they are frequently disturbed.

The characteristics of riverine environments are determined by the flow of water. River and stream ecosystems are maintained by

* Corresponding author; Phone: +82-2-970-5666, e-mail: leecs@swu.ac.kr 
both their vegetation and the morphology of the river or stream, which is in turn created by the flowing water. Rivers and streams are dynamic ecological spaces where disturbances such as erosion, transport, and deposition of sediments are constant (Lee et al. 1999). Tsujimoto $(1998,1999)$ clarified that sand and gravel bars are expanded toward downstream and upstream, respectively through his experiments on formation and expansion of sand and gravel bars in relation to vegetation established in the river. Choi et al. (2004, 2005) verified the process by which sand bars are formed based on vegetation data. Our study aimed to clarify the differences in vegetation succession and the factors driving succession in two types of rivers with different river bed substrates.

\section{METHODS}

\section{Study Area}

Our investigation of a sand bar was carried out in the Yongsu Stream $\left(36^{\circ} 27^{\prime} 54.4^{\prime \prime} \mathrm{N}, 127^{\circ} 15^{\prime} 44.4^{\prime \prime} \mathrm{E}\right)$, which is a tributary of the Geum River. Study sites were chosen around downstream of the Yongsu Stream where the stream meets with the main body of the Geum River. The slope of the river bed in this area is gentle and therefore the current is slow and water is relatively deep. This stretch of the stream forms a typical sand stream. The sand bar chosen as a model site was covered with grasslands and woody plant stands. The grasslands were composed of two kinds of plant communities: annual plant communities dominated by Rorippa palustris, Lindernia procumbens, Persicaria nodosa, and Potentilla supine, and perennial plant communities dominated by Phalaris arundinacea and Miscanthus sacchariflorus. The woody plant stands were dominated by Salix koreensis.

Our investigation of a gravel bar was conducted on the Buk Stream ( $\left.38^{\circ} 11^{\prime} 39.2^{\prime \prime} \mathrm{N}, 128^{\circ} 19^{\prime} 52.6^{\prime \prime} \mathrm{E}\right)$, which is a tributary of the Naerin Stream. Study sites were chosen around upstream of the Buk Stream. The slope of the river bed in the study area is relatively steep and the current is rapid. This area of the stream forms a typical gravel stream, and most of the floodplain of the stream is very dry, except for a narrow area along the watercourse. The gravel bar chosen as a model site is covered with grasslands and Korean red pine (Pinus densiflora) stands. The grassland is composed of coarse stands where Artemisia princeps var. orientalis, Phragmites japonica, Humulus japonicus, P. densiflora (seedling), Populus maxomowiczii and other grasses are sparsely scattered. The Korean red pine stands are comprised of young and mature stands, as well as mixed stands of young and mature pines.

\section{Methods for Vegetation Surveys}

Fifty-four plots were placed randomly on the sand bar for vege- tation sampling. The study plots were placed in areas that included eight woody, thirty-four perennial herb, and twelve annual plant communities. Twenty-seven plots were established on the gravel bar, sampling thirteen herb communities and six young pine, four two-layered, and four mature pine stands. Plot sizes were $1 \times 1 \mathrm{~m}$ in herbaceous vegetation, $2 \times 2 \mathrm{~m}$ in shrub lands, and $10 \times 10 \mathrm{~m}$ in tree-dominated vegetation.

We recorded the occurrence and dominance of all plant species in the study plots on the sand and gravel bars (Braun-Blanquet 1964, Müeller-Dombois and Ellenberg, 1974), following the nomenclature of Lee (1985), and the Korean Plant Names Index (Korea Forest Service 2003). Dominance was estimated using the ordinal class scale (from 1 for $<1 \%$ to 5 for $>75 \%$ ) of Braun Blanquet (1964). We then converted the dominance estimate to the median value for percentage of coverage for each class, and subjected the converted estimates to Detrended Correspondence Analysis (DCA) for ordination (Hill 1979). We constructed rank-abundance curves following Magurran (2003) and Kent and Cocker (1992), and calculated species diversity $\left(\mathrm{H}^{\prime}\right)$ following Shannon (1948). Species richness was determined simply as the number of species occurring in each area. In addition, stem diameters of major species were measured using a tape ruler to the nearest $\mathrm{mm}$ and then sorted into 5 -cm intervals. Stand profiles were prepared depicting major plants that appeared in each longitudinal section of each bar.

\section{RESULTS}

\section{Stand Profile}

Fig. 1 depicts the vegetation on the sand bar. A woody plant community (dominated by Salix), a perennial herb community (dominated by Phalaris), and an annual plant community (dominated by Persicaria) appeared in that sequence from upstream to downstream on the sandbar (Fig. 1). This result suggests that the sandbar grew from upstream to downstream, with the downstream area forming most recently.

Three Korean red pine (Pinus densiflora) communities of different developmental stages (young pine stands, two-layered stands of young and mature pines, and mature pine stands) and a grassland had become established on the gravel bar (Fig. 2). The grassland was composed of coarse stands of sparsely scattered Artemisia princeps var. orientalis, Phragmites japonica, Humulus japonicus, P. densiflora (seedling), Populus maxomowiczii and other species. Grassland, young pine, two-layered pine, and mature pine stands appear in that order from upstream to downstream on the gravel bar (Fig. 2). This result suggests that the upstream area of the gravel bar formed most recently. 


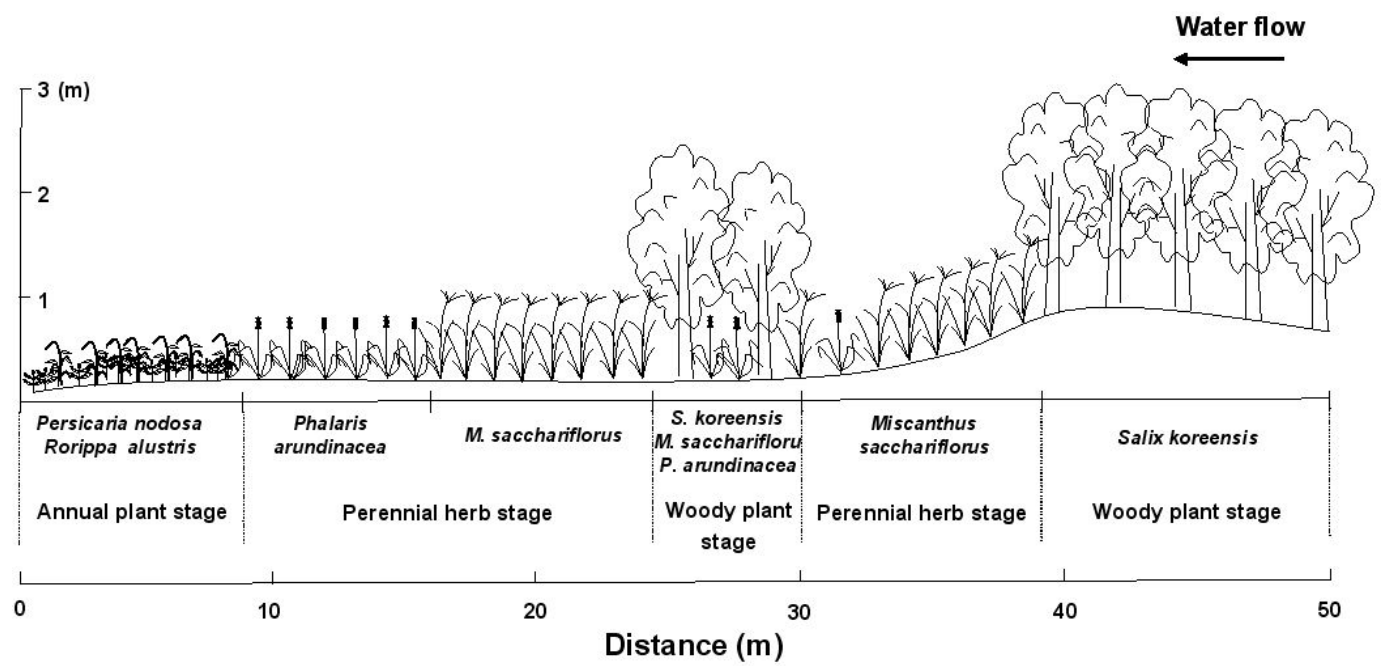

Fig. 1. A diagram showing the stand profile from upstream to downstream for vegetation on a sandbar in the Yongsu Stream, a tributary of the Geum River.

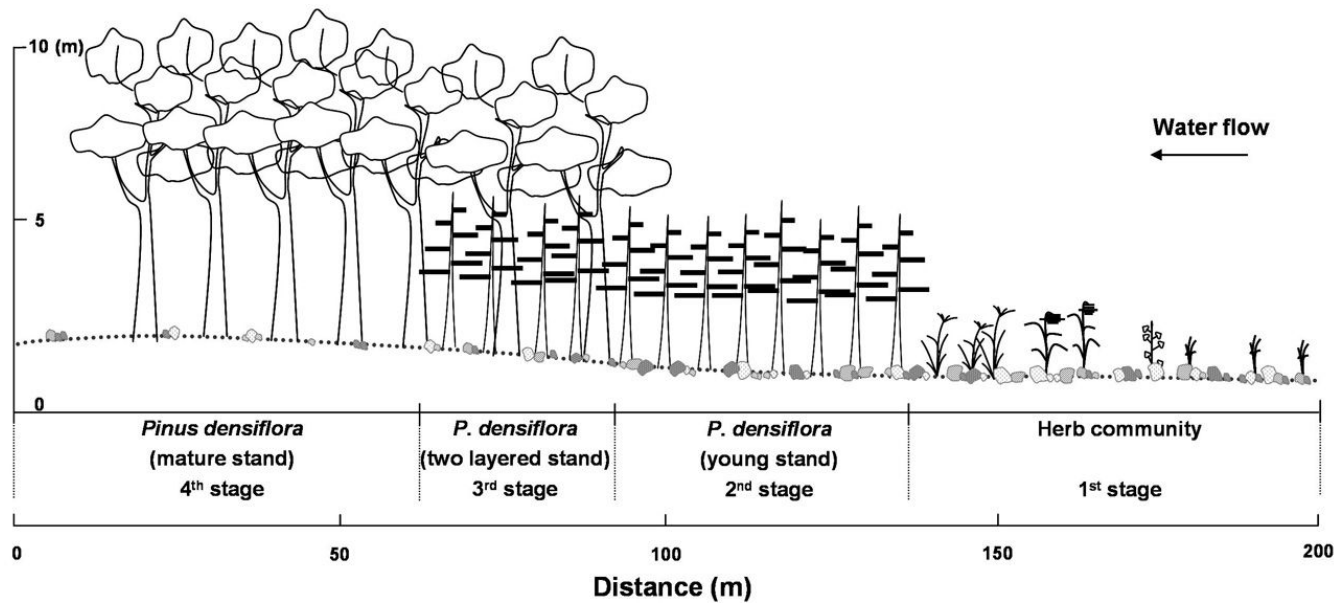

Fig. 2. A diagram showing the stand profile from upstream to downstream for vegetation on a gravel bar in the Buk Stream, a tributary of the Naerin Stream.

\section{Stand Ordination Based on Vegetation Data}

The DCA ordination of the vegetation data from the sand bar arranged the stands in a sequence corresponding to the successional trend (Fig. 3), producing the same pattern shown in the diagram of the stand profile (Fig. 1). The arrangement of stands in the DCA ordination of the vegetation data from the gravel bar also reflected the successional trend (Fig. 4). Stands were arranged in the following sequence from upstream to downstream: grassland, young pine stands, two-layered stands of young and mature pines, and mature pine stands. This result verified that vegetation succession is newly initiated in the upstream area of the gravel bar.

\section{Species Diversity}

Species richness was highest in woody plant-dominated stands, followed by perennial herb-, and annual plant-dominated stands, and the slope of rank-abundance curve was also gentler in woody plant-dominated stands than perennial or annual plant-dominated stands on the sand bar (Fig. 5). Shannon-Wiener's index was the highest in perennial herb-dominated stand, followed by annual, and woody plant-dominated stands on the sand bar (Fig. 5).

Species richness on the gravel bar was highest in the young pine stand, followed by the mature pine stand and the mixed stand of young and mature pines, and was lowest in the herb community (Fig. 6). The rank-abundance curve was steep for the herb community, which is typical in the establishing stage. Those of the young, mixed, and mature pine stands were all sigmoid in shape, although they differed in richness. Shannon-Wiener's index was the highest in the young pine stand, followed by the herb-dominated stand and 
the mature pine stand, and was the lowest in the mixed stand on gravel bar (Fig. 6).

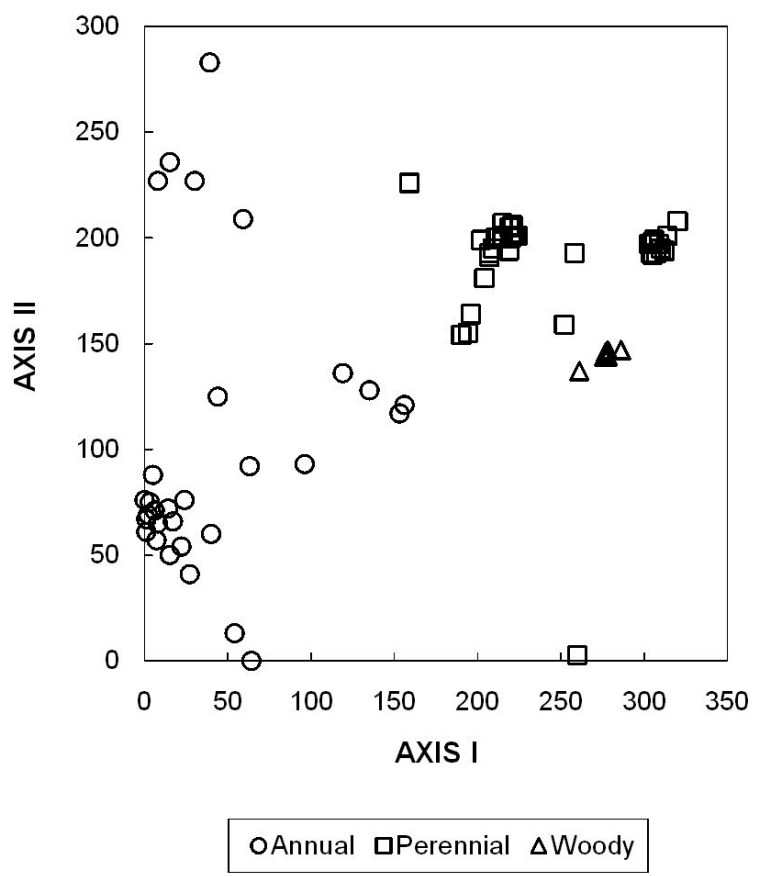

Fig. 3. Stand ordination based on vegetation data collected on the sand bar. Annual: dominated by Rorippa palustris, Lindernia procumbens, Persicaria nodosa, and Potentilla supine. Perennial: dominated by Phalaris arundinacea and Miscanthus sacchariflorus. Woody: dominated by Salix koreensis.

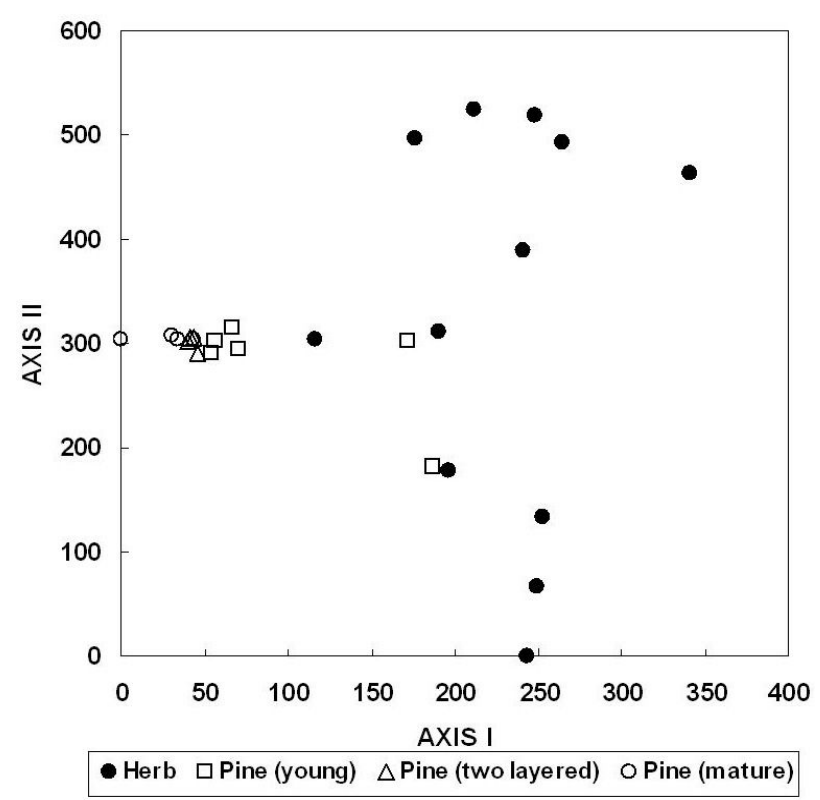

Fig. 4. Stand ordination based on vegetation data collected on the gravel bar.

\section{Vegetation Dynamics}

We compared the frequency distribution of diameter classes of major woody plants among the Korean red pine stands in different developmental stages (Fig. 7). Young pine stands are composed of individuals $<10 \mathrm{~cm}$ in diameter, and most individuals were $<5 \mathrm{~cm}$

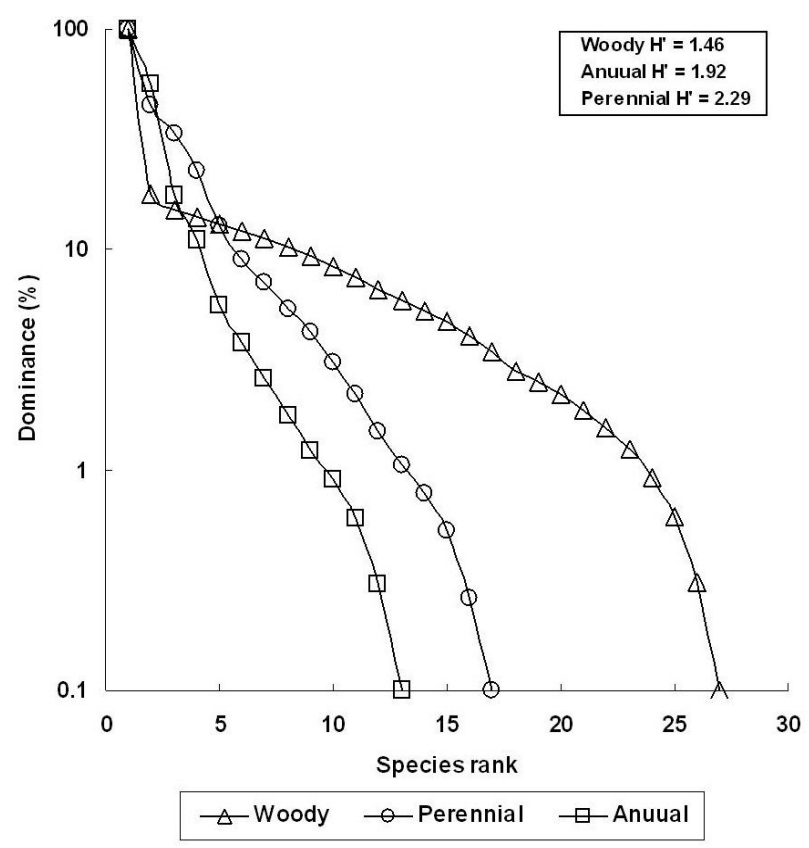

Fig. 5. Rank-abundance curves and $\mathrm{H}^{\prime}$ of vegetation on a sand bar in the Yongsu Stream.

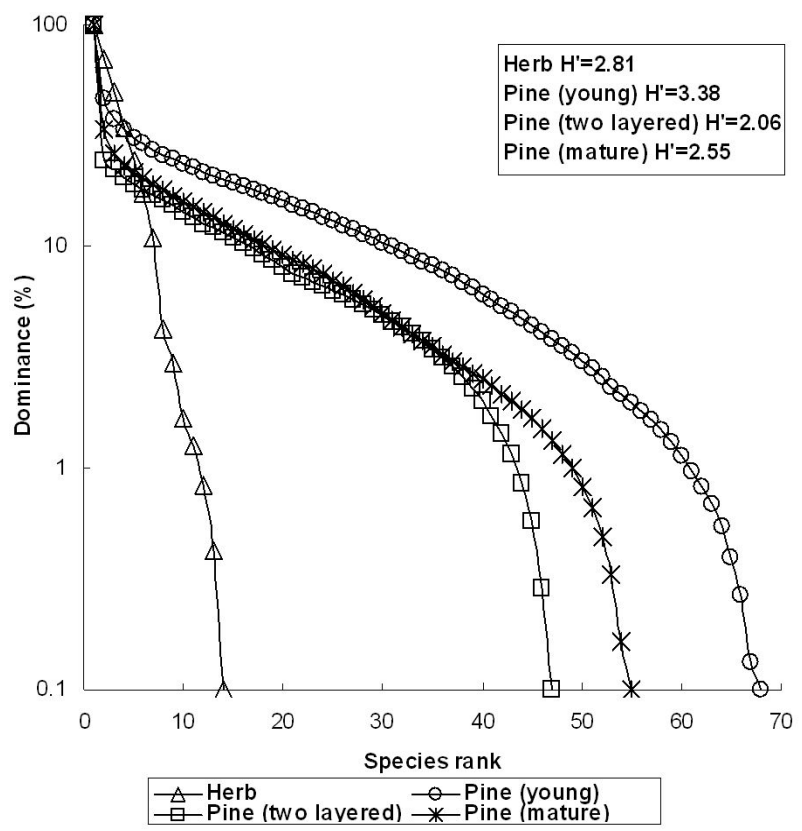

Fig. 6. Rank-abundance curves and $\mathrm{H}^{\prime}$ of vegetation on a gravel bar in the Buk Stream. 
in diameter. Mixed pine stands consisted of both young and mature pines, but young pines comprised a far higher percentage of trees in mixed stands than mature pines. The mature pine stands included representatives of each diameter class in relatively even numbers,

Pine (young)

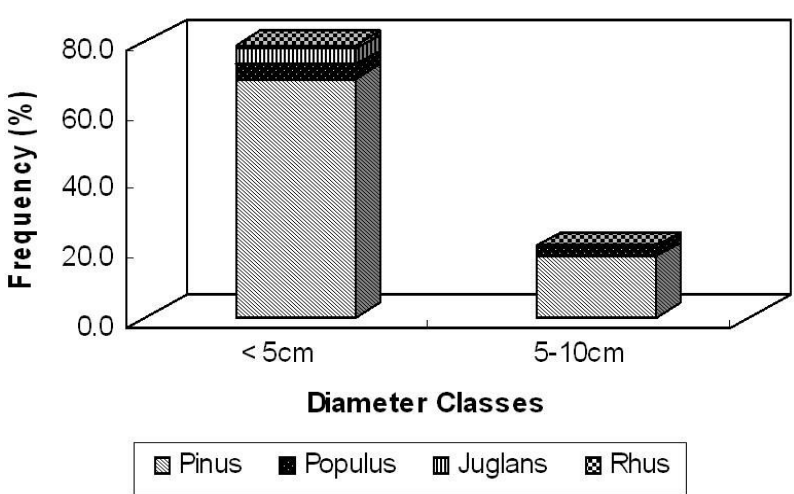

Pine (two layered)

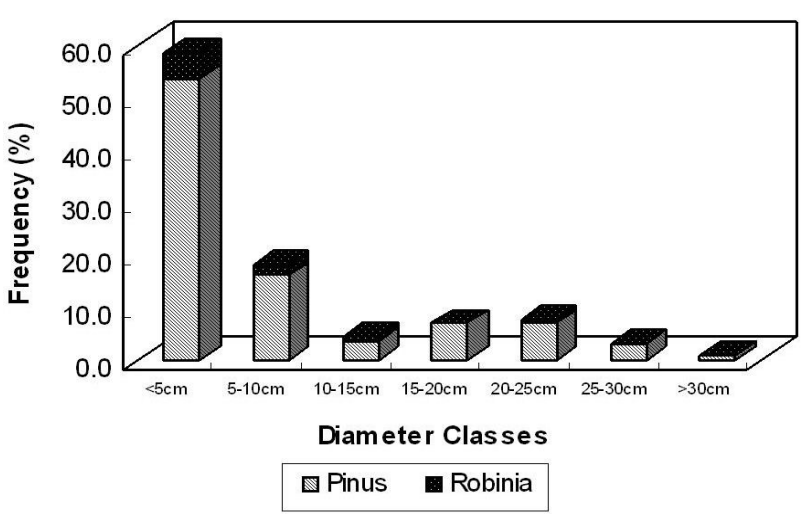

Pine (mature)

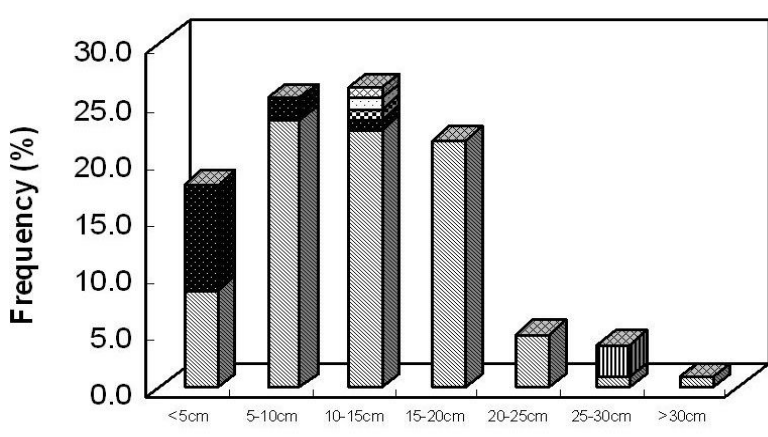

Diameter Classes

बPinus Robinia mPopulus $\mathbf{m}$ Juglans $\square$ Acer $\mathbf{m}$ Fraxinus

Fig. 7. Frequency distribution of diameter classes of major tree species in the vegetation on a gravel bar. but individuals of the intermediate size classes were more common than small and large ones. Moreover, young pines were restricted to the edge of gravel bar, which experienced frequent disturbance, being absent from the relatively stable interior.

\section{DISCUSSION}

\section{Spatial Distribution and Dynamics of Bed Loads}

Sand bars are primarily composed of sand, but finer particles appear around sand bar tails. Annuals, such as Rorippa palustris, Lindernia procumbens, Potentilla supina, etc., usually establish themselves on this sand bar tail. The distribution of substrates of different particle sizes is similar in gravel bars. Cobbles cover the whole gravel bar, but most new deposition occurs in the upstream area of the gravel bar, which are covered with stands of grass land and young pine stand, whereas the coverage decreases in the downstream area of the gravel bar, the surface of which is covered with sand transported by floating during floods. Unlike sand bars, gravel bars do not form a tail: the rear edge is covered with cobbles.

Sands suspended by running water can be transported downstream over the vegetated area of a sand bar and be deposited to create new areas of sandbar in the downstream section of the bar (Tsujimoto 1999). Meanwhile, gravel, which is heavier, is transported by rolling, and accumulates upstream of the vegetated area and thus creates new areas of gravel bar in that direction (Tsujimoto 1998). Both the spatial distribution diagrams (Figs. 1 and 2) and the results of the ordination of vegetation (Figs. 3 and 4) are consistent with the interpretation that these allogenic processes are primary drivers of vegetation dynamics on sand and gravel bars in streams and rivers.

\section{Responses of Vegetation to Bed Load Dynamics}

In the stand ordination of vegetation on the sand bar, stands of the late successional stages tended to be clustered, whereas those of the early stage were widely scattered. This wide dispersion in the early-stage stands probably results from the invasion of various herbaceous plants into the heterogeneous spaces created by deposition of suspended sands during floods (Tsujimoto 1999). On the gravel bar as well, stands of the early stages were scattered widely on the ordination plot, whereas those of the late stages were clustered. Wide dispersion of stands in the early stages of succession is the result of invasion by various herbaceous plants into the heterogeneous spaces created by the deposition of gravel before the establishment of dominant vegetation types. Heavy cobbles are transported by rolling and thereby accumulate on the upstream end of the gravel bar, whereas light sands, which can be suspended in water, are transported farther, and tend to settle down on the down- 
stream part of the gravel bar (Tsujimoto 1998).

Changes in species diversity were consistent with changes in the developmental stages of vegetation on the sand bar (Fig. 5). On the gravel bar, however, the young pine stand, which was located immediately behind the herbaceous vegetation on the upstream end of the gravel bar and was composed of young, shrub-level pines, showed the highest species diversity. This result may be due to moderate disturbance at this site (Pickett 1980). Lower species diversity in the mixed and mature pine stands might be related to shading in the two-layered mixed pine stand and frequent disturbance due to the accumulation of sand from flooding during the rainy season in the mature pine stand. The characteristics of the upstream ecosystem, which experiences intense disturbance and lacks forest (shade tolerant) species, may be an additional explanation for the pattern of species diversity. The Shannon-Wiener's index also indicated that the young pine stands had the highest species diversity on gravel bars.

In conclusion, the dynamics of bed loading, an allogenic process, may be an important determinant of the structure and succession of plant communities in dynamic riverine environments. This suggests that riverine ecosystems respond to a different set of forces than more stable terrestrial ecosystems, where autogenic processes dominate the sequence of vegetation change.

\section{ACKNOWLEDGMENTS}

This study was supported by the research grant of Seoul Women's University.

\section{LITERATURE CITED}

Barbour MG, Burk JH, Pitts WD, Gilliam FS, Schwartz MW. 1999. Terrestrial Plant Ecology. 3rd ed. The Benjamin/Cummings Co., Menlo Park.

Bliss LC, Cantlon JE. 1957. Succession on river alluvium in northern Alaska. Am Midl Nat 58: 452-469.

Braun-Blanquet J. 1964. Pflanzensoziologie. Grundze der Vegetaionskunde. Springer-Verlag, Vienna, Austria.

Choi SU, Yoon B, Woo H. 2005. Effects of dam-induced flow regime change downstream river morphology and vegetation cover in the Hwang River, Korea. River Res Applic 21: 315-325.

Choi SU, Yoon B, Woo H, Cho KH. 2004. Effect of flow-regime change due to damming on the river morphology and vegetation cover in the downstream river reach: a case of Hapcheon dam on the Hwang River. Korea Water Resource Ass 37: 55-66.

Chun YM, Park SA, Lee CS. 2007. Structure and dynamics of Korean red pine stands established as riparian vegetation at the Tsang stream in Mt. Seorak National Park, eastern Korea. J Ecol Field Biol 30: 347-356.
Clements FE. 1916. Plant Succession: Analysis of the Development of Vegetation. Carnegie Institute of Washington Publication, No 242, Washington DC.

Décamps H. 1996. The renewal of floodplain forest along rivers: a landscape perspective. Verh Internat Verein Limnol 26: 35-59.

Fonda RW. 1974. Forest succession in relation to river terrace development in Olympic National Park, Washington. Ecology 55: 927-942.

Hill MO. 1979. DECORANA - A FORTRAN program for detrended correspondence analysis and reciprocal averaging. Cornell University Ithaca, New York.

Korea Forest Service. 2003. Korea Plant Names Index. http://www.koreaplants.go.kr: 9101/. Accessed 13 February 2009.

Kent M, Cocker P. 1992. Vegetation Description and Analysis: A Practical Approach. CRC Press, Boca Raton, Florida.

Lee CS, Hong SG, Cho HJ, Oh JM. 1999. Technique of Natural Environment Restoration. Dong Hwa Technology Publishing, Seoul.

Lee TB. 1985. Illustrated Flora of Korea. Hyangmunsa, Seoul. (in Korean)

Magurran AE. 2003. Measuring Biological Diversity. Blackwell, New York.

McCook LJ. 1994. Understanding ecological community succession: Causal models and theories, a review. Vegetation 110: 115-147.

Miles J. 1979. Vegetation Dynamics. Chapman and Hall, London.

Müeller-Dombois D, Ellenberg H. 1974. Aims and Methods of Vegetation Ecology. Wiley, New York.

Pickett STA. 1980. Non-equilibrium coexistence of plants. Bull Torrey Bot Club 107: 238-248.

Shannon CE. 1948. A mathematical theory of communication. Bell Syst Technol J 27: 379-423, 623-656.

Tsujimoto T. 1998. Development of sand island with vegetation in fluvial fan river under degradation. In Proceedings of Water Resources Engineering 198, vol. 1, (Apt SR, ed). ASCE: Reston, VA, pp 574-579.

Tsujimoto T. 1999. Fluvial processes in streams with vegetation. J Hydraulic Res 37: 789-803.

van Andel J, Bakker JP, Grootjans AP. 1993. Mechanisms of vegetation succession: a review of concepts and perspectives. Acta Bot Neer 42: 413-433.

van der Maarel E, Sykes MT. 1993. Small-scale plant species turnover in a limestone grassland: the carousel model and some comments on the niche concept. J Veg Sci 4: 179-188.

Walker LR, Chapin FS III. 1986. The role of life history processes in primary succession on an Alaskan floodplain. Ecology 67: 12431253.

Watt AS. 1947. Pattern and process in the plant community. J Ecol 35: $1-22$.

Weaver JE. 1960. Flood plain vegetation of the central Missouri Valley and contacts of woodland with prairie. Ecol Monogr 30: 37-64.

White PS, Pickett STA. 1985. Natural disturbance and patch dynamics: an introduction. In Disturbance and Patch Dynamics (Pickett STA, White PS, eds). Academic Press, New York. pp 3-13.

Wistendahl WA. 1958. The floodplain of the Raritan River, New Jersey. Ecol Monogr 28: 129-153.

(Received February 15, 2009; Accepted February 23, 2009) 